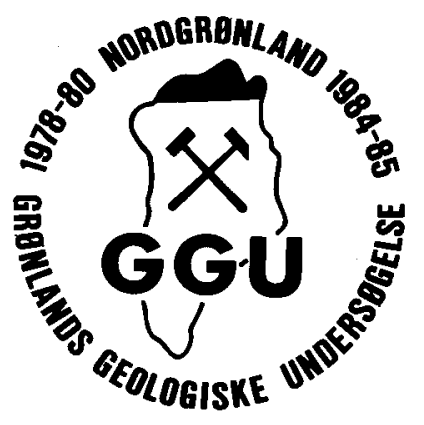

\title{
Lithostratigraphy and depositional history of Upper Ordovician - Silurian shelf carbonates in central and western North Greenland
}

\author{
M. Sønderholm, T. L. Harland, P. H. \\ Due, L. N. Jørgensen and J. S. Peel
}

Field work in 1985 revealed that the Aleqatsiaq Fjord Formation (Ordovician-Silurian) can be traced from Washington Land to westernmost Peary Land, and that a tripartite subdivision of the formation can be achieved throughout most of this area (units AF1-3). Five mapping units (WG1-5) were recognised within the overlying Washington Land Group of Silurian age between Hall Land and westernmost Peary Land. These are described and correlated with sequences in Washington Land and elsewhere in Peary Land. Deposition was uniform in the lower part of the sequence (units AF1-WG1) throughout the mapped area. Lateral lithological variation in the upper part (units WG2-5) reflects differential regional subsidence, the presence of intrashelf mounds and the development of huge mound complexes along the shelf margin.

M. S. \& J. S. P., Grønlands Geologiske Undersøgelse, Øster Voldgade 10, DK-1350 Copenhagen K, Denmark.

T. L. H., Poroperm Laboratories Ltd, Chester Street, Chester CH4 8RD, U. K.

P. H. D., DOPAS A/S, Agern Alle 20-26, DK-2970 Hørsholm, Denmark.

L. N. J., Marsk Olie \& Gas, Rønnegade 2, DK-2100 Copenhagen $\varnothing$, Denmark.

During the 1985 field season, Silurian shelf carbonates were mapped from Petermann Gletscher in the west to J. P. Koch Fjord in the east by three mapping teams who established a total of 29 camp positions (fig. 1). In addition to mapping, lithological sections were logged at the majority of the camp positions. One additional camp was established in the southern part of Bessels Fjord in Washington Land to assess how the detailed stratigraphy of the Washington Land Group defined by Hurst (1980a) correlated with the stratigraphy established across North Greenland in 1985. Tentative correlations to the established stratigraphic schemes in Washington Land and Peary Land (fig. 2) are suggested. Verification of these correlations must await further study associated with the erection of a formal stratigraphic nomenclature for the region mapped during 1985. 


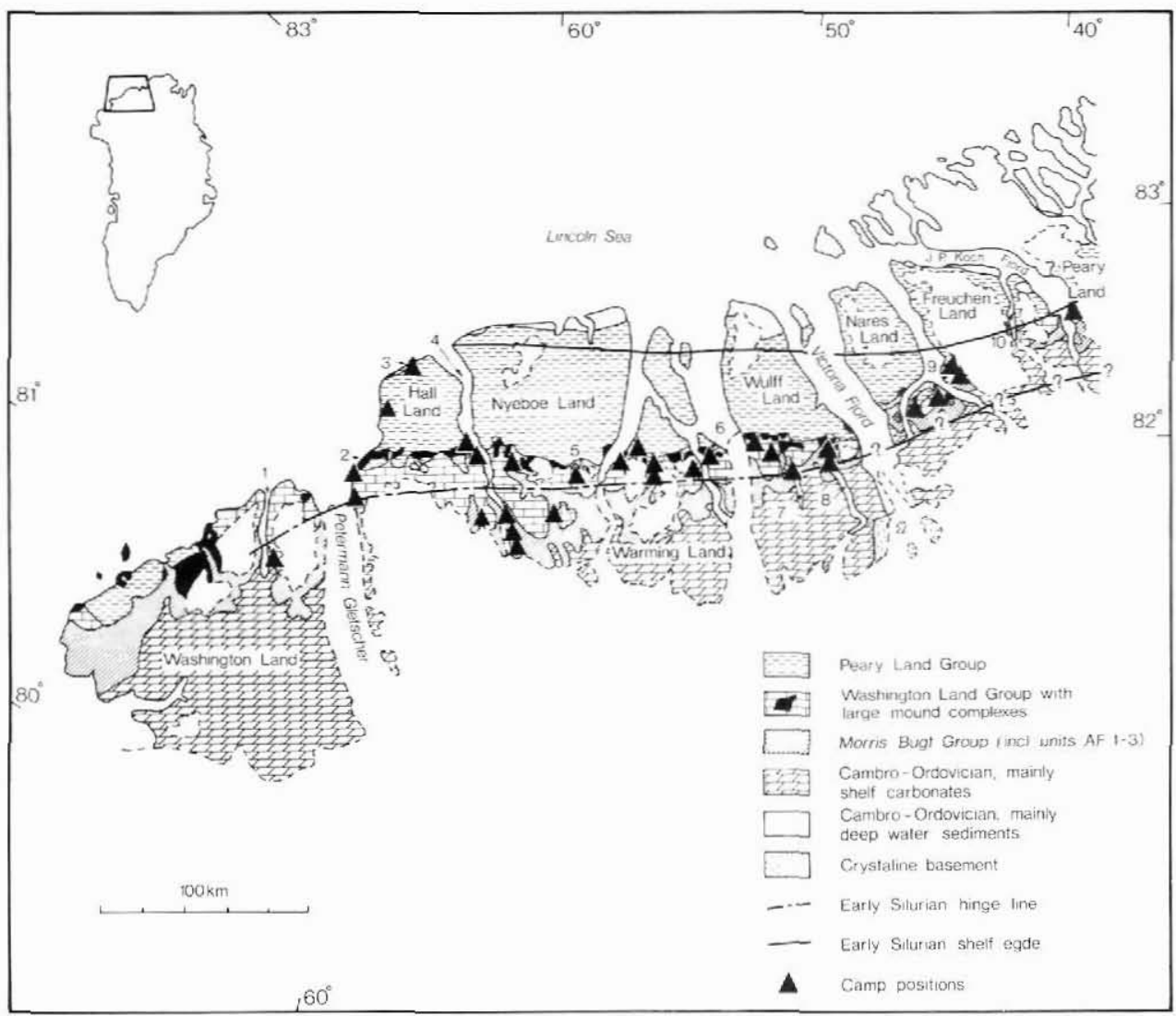

Fig. 1. Simplified geological map of western and central North Greenland showing camp sites from the 1985 season. The map is based on GGU's field work in the region (Map 1, Henriksen 1987). 1: Bessels Fjord, 2: Kap Tyson, 3: Kap Ammen, 4: Newman Bugt, 5: Dreyer Firn, 6: Permin Land, 7: 'Aphrodite Sø:, 8: Apollo Sø, 9: Nordenskiöld Fjord, 10: Navarana Fjord.

\section{Stratigraphy}

Three groups of mapping units of regional extent were recognised, and widespread subdivision of the two lower of these was feasible (figs 1, 2 \& 9).

\section{Aleqatsiaq Fjord Formation}

Strata placed here include shelf carbonates of Late Ordovician - Early Silurian age, and are recognisable across the region. Three lithologically distinct units (AF1-3) are well defined and mappable in most areas (fig. 3).

Unit $A F 1$. This unit consists of dark grey to very dark grey lime mudstones and bioclastic wackestones which exhibit a characteristic brownish mottling produced by horizontal burrow systems. Where weathered, the unit appears to be thin to medium bedded but it ty- 


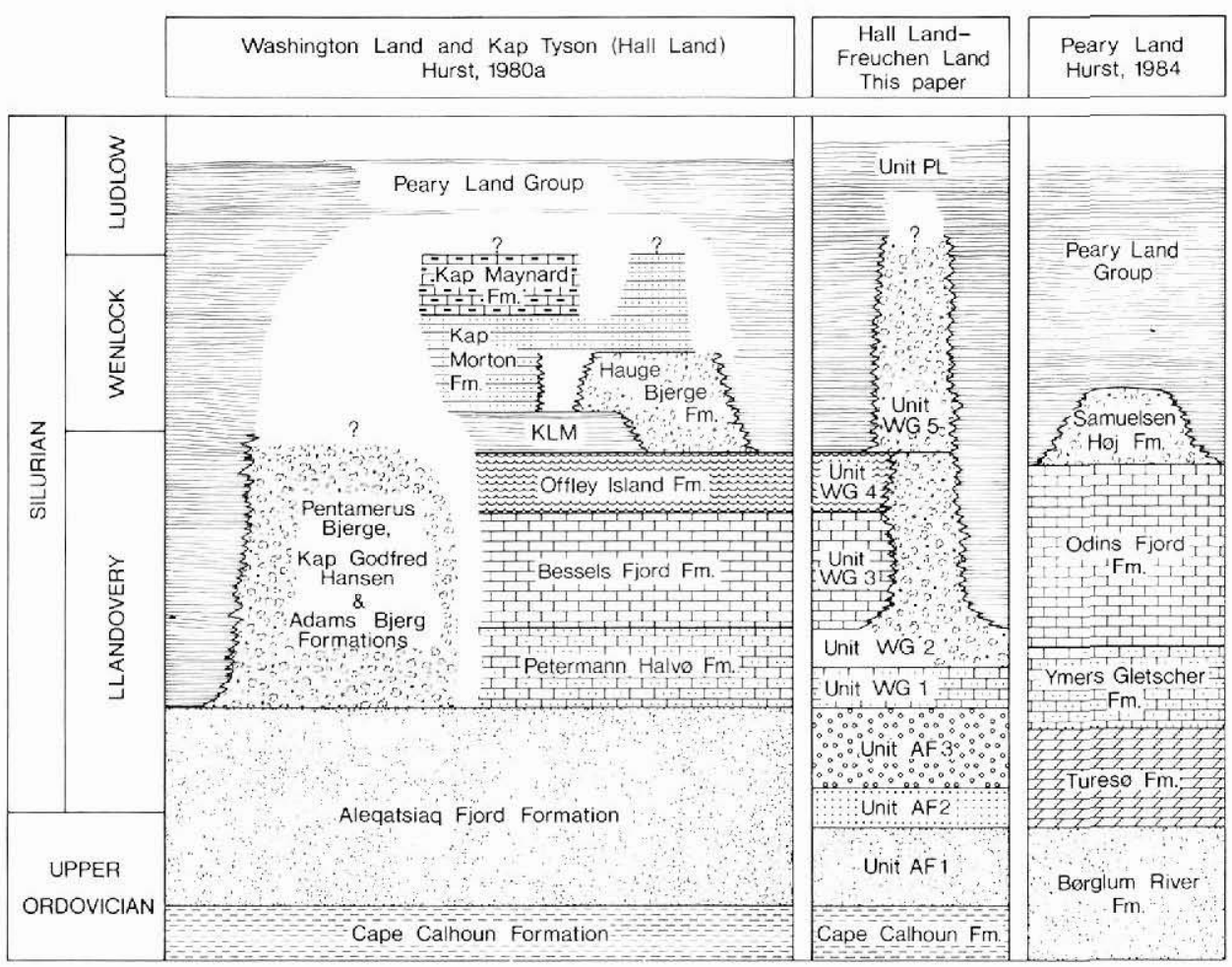

Fig. 2. Stratigraphic scheme for uppermost Ordovician to Silurian shelf carbonates in North Greenland with proposed correlations of mapping units with the schemes of Washington Land and Peary Land. KLM: Kap Lucie Marie Formation.

pically forms massive bedded cliffs above the recessive Cape Calhoun Formation (fig. 3). Unit AF1 is of fairly uniform thickness throughout the region, thinning from a measured maximum of $160 \mathrm{~m}$ by south Newman Bugt to approximately $120 \mathrm{~m}$ near the northern limit of the carbonate outcrop belt. At Kap Ammen, in northern Hall Land, a minimum thickness of $100 \mathrm{~m}$ was measured. The gastropod Maclurites, indicating an Ordovician age, occurs throughout. Satisfactory delimitation of the lower boundary of unit AF1 was not practicable in outcrops east of Navarana Fjord due to the absence of the underlying recessive Cape Calhoun Formation. In these areas, strata equivalent to the Gonioceras Bay and Troedsson Cliff Formations of Washington Land (Peel \& Hurst, 1980), together with unit AF1, are referred to the Børglum River Formation (fig. 2), originally defined in central Peary Land to the east (Troelsen, 1949; Christie \& Peel, 1977). Thus, at J. P. Koch Fjord the Børglum River Formation, the upper part of which has the lithological character of unit AF1, is overlain by unit AF2, described below.

Unit $A F 2$. This unit comprises variable biostromal and skeletal limestones and is usually mainly light to medium grey and massively bedded. In situ stromatoporoids and corals are locally abundant and contribute to the formation of small mounds in some areas, for exam- 

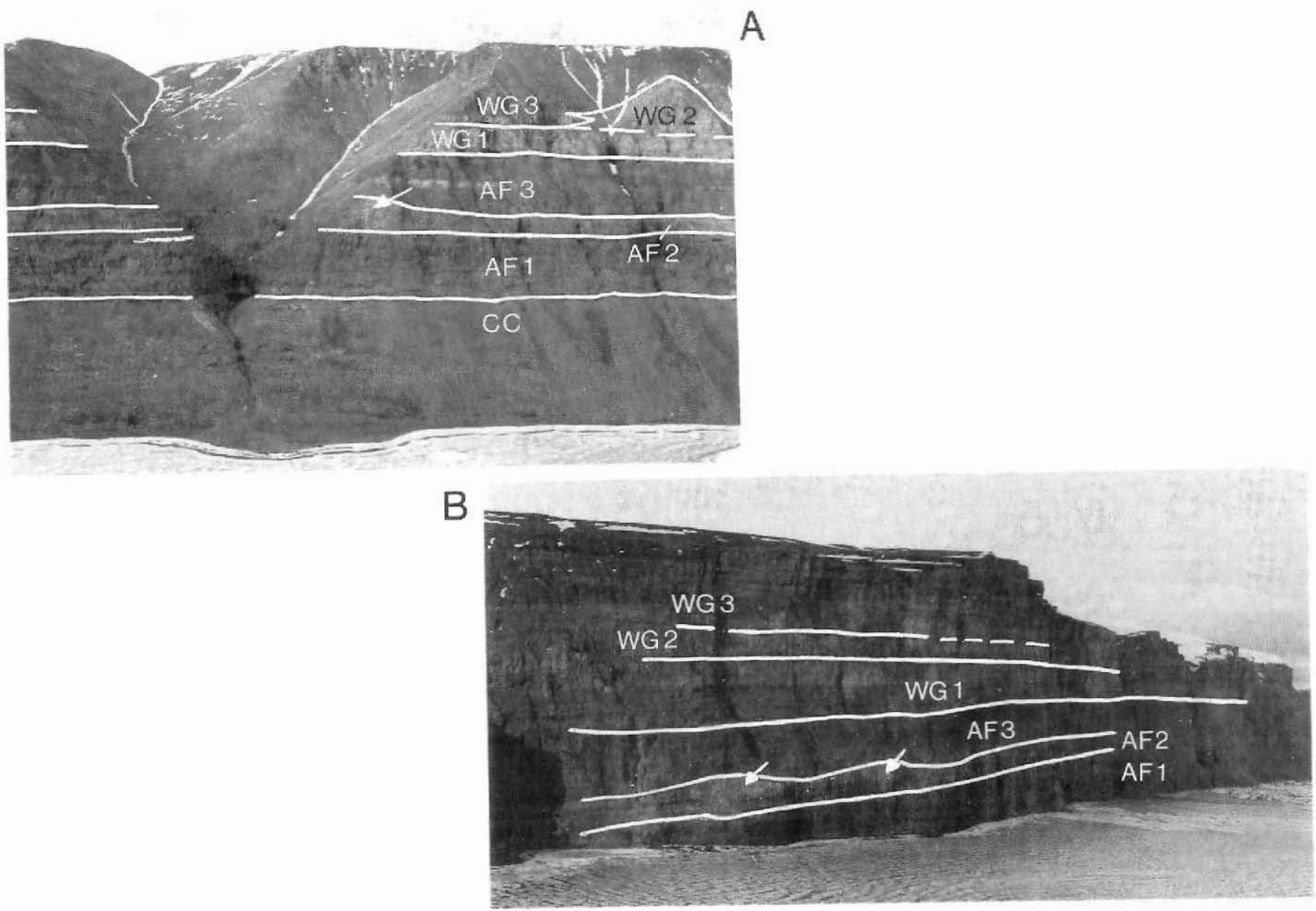

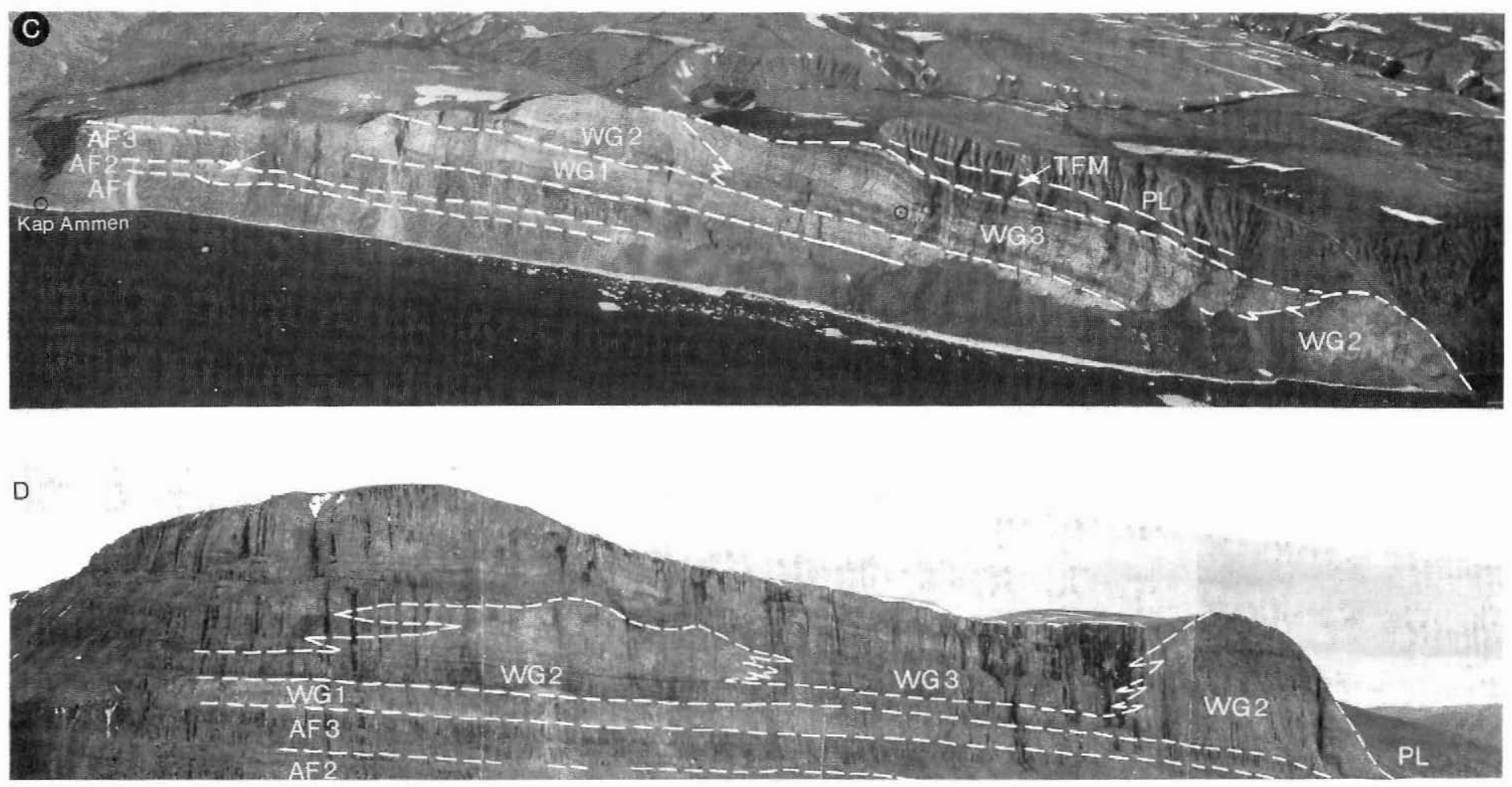

Fig. 3. Lower part of the Upper Ordovician - Silurian carbonate shelf sequence as developed, A: in southern Bessels Fjord, Washington Land (cliff height c. $800 \mathrm{~m}$ ), B: at Petermann Gletscher, southern Hall Land (cliff height c. $750 \mathrm{~m}$ ), C: at Kap Ammen, northern Hall Land. (cliff height c. $735 \mathrm{~m}$ ), aerial photograph 546 K-S no. 2190, copyright Geodætisk Institut, Denmark (A.495/79), and D: in southern Nordenskiöld Fjord, eastern Nares Land (cliff height $c .650 \mathrm{~m}$ ). CC indicates Cape Calhoun Formation, TFM indicates Thors Fjord Member (Peary Land Group) and other numbers and letters refer to map units in text. Arrows indicate mound-development in unit AF2. Note the close similarity between the southern sequences (A, B) and the sequences close to the shelf margin $(C, D)$. 
ple in southern Bessels Fjord (fig. 3A), western Hall Land (fig. 3B) and at Kap Ammen (fig. 3C). Maclurites occurs rarely near the base of the unit. A graptolite assemblage containing Climacograptus inuiti indicating an uppermost Ordovician, possibly Gamachian age (M. Bjerreskov, personal communication, 1986), has been recovered from shales at the base of the unit. Unit AF2 is generally cliff-forming and light weathering, whilst its thickness is variable, usually $50-80 \mathrm{~m}$. In areas east of Wulff Land unit AF2 often contains light weathering dolomites and dolomitic limestones.

Unit AF3. This unit consists of dark, strongly mottled, bituminous fine-grained skeletal limestones with abundant pentameroid brachiopods. Where deeply weathered, the lithology is a dark grey to black, nodular limestone, and the unit is everywhere relatively recessive (fig. 3). The upper beds may include stromatoporoids and corals and are locally transitional up into the lighter weathering beds of unit WG1 (fig. 3B). Thickness varies between $65 \mathrm{~m}$ and $80 \mathrm{~m}$, though the unit thickens to $110 \mathrm{~m}$ at Kap Ammen in northern Hall Land. The dark dolomites and dolomitic limestones of unit AF3 in the area around Navarana Fjord and $\mathbf{J}$. P. Koch Fjord contain thin beds of pale microcrystalline dolomite.

Correlation. Units AF1-3 correspond to the Aleqatsiaq Fjord Formation of the Morris Bugt Group (Peel \& Hurst, 1980) as seen in the Bessels Fjord area of Washington Land (Hurst, 1980a), where the tripartite subdivision is clearly recognisable in the sides of the fjord (fig. $3 \mathrm{~A})$. It is not possible, at this time, to ascertain the precise relationship between unit AF1-3 and the type section of the Aleqatsiaq Fjord Formation at Aleqatsiaq Fjord, western Washington Land, as described by Hurst (1980a). The sequence in the type area is reduced in thickness relative to Bessels Fjord, and the published sections and descriptions do not permit precise correlation. In the area around Navarana Fjord and J. P. Koch Fjord, units AF2-3 correspond to the Dolomite formation and Dark limestone formation of Hurst (1979), respectively. These latter two formations correspond to the Tures $\varnothing$ Formation in central Peary Land (Hurst, 1984) (fig. 2).

\section{Washington Land Group}

This lithologically diverse and complex suite of sediments forms the upper part of the Silurian carbonate sequence across the region. Five units have been recognised and are described below.

Unit WG1. This unit consists of predominantly light grey to dark grey skeletal limestones, usually rich in laterally extensive coral and stromatoporoid colonies. Crinoidal debris is locally abundant. Unit WG1 is primarily a flat bedded sequence, occurring at the base of the Washington Land Group (figs 3, 4 \& 5). In places, however, bedding becomes more irregular and indistinct in the upper part of the unit where carbonate mounds are developed. In the southern part of the outcrop belt, the skeletal limestones of this unit have been variably dolomitised. Unit WG1 is cliff-forming, and its characteristic light grey to yellow-grey weathering makes it a useful marker horizon across the region. Thickness is variable and difficult to assess where the upper parts are transitional to overlying carbonate mounds. Overall, however, a thickness of 90 to $120 \mathrm{~m}$ is estimated, with a slight general thinning from south to north across the whole region. 


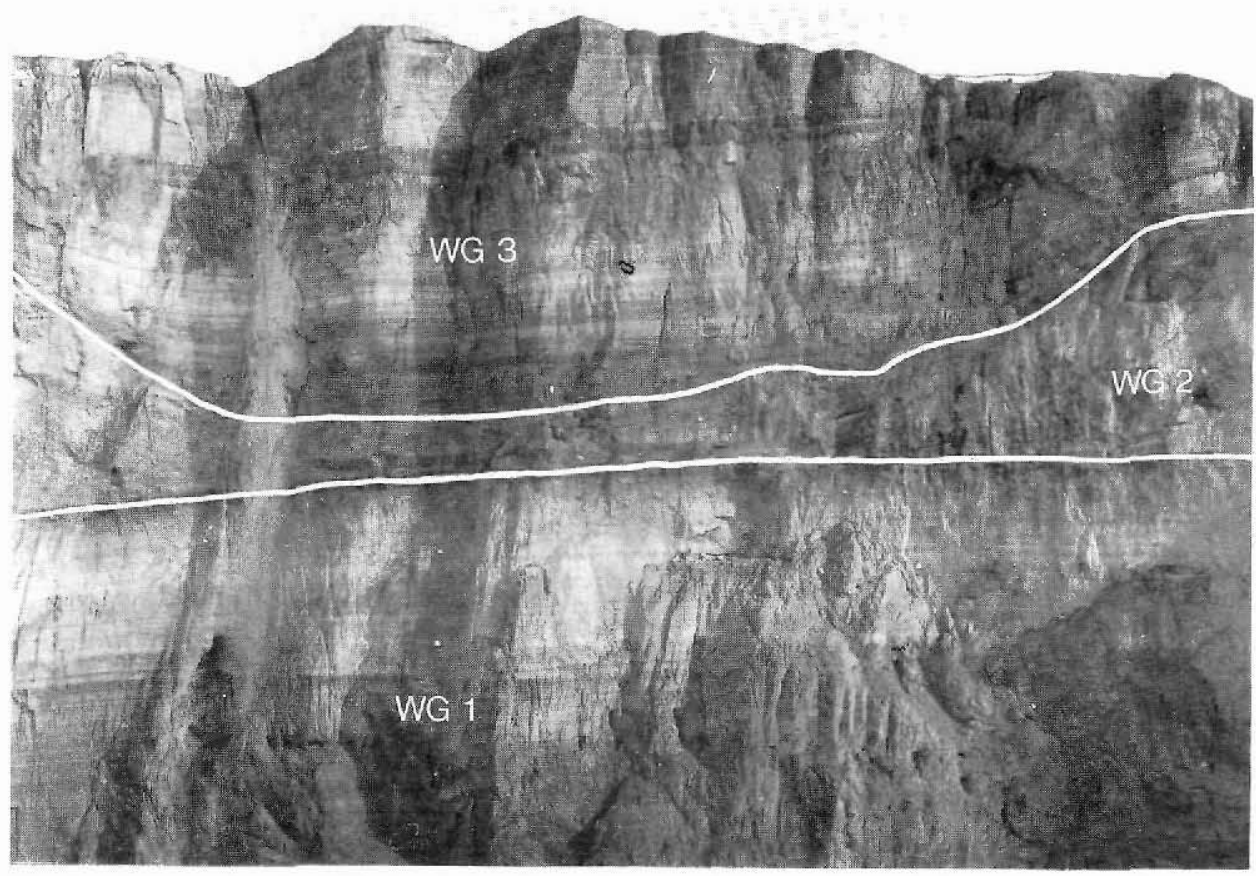

Fig. 4. Mounds of unit WG2 developing from the top of flat-bedded unit WG1, eastern side of Petermann Gletscher, Hall Land. Between the mounds, dark intermound deposits of unit WG3. Height of section c. $350 \mathrm{~m}$.

Unit WG2. Where developed, this unit comprises massive or irregularly bedded lime mudstones and fine-grained skeletal limestones, with tabular stromatoporoids and colonial corals. This unit occurs as a series of mounds developed from underlying flat bedded sediments of unit WG1 (figs 3A \& 4), and is mainly overlain and bounded laterally by darker, thinner bedded intermound sediments (see below). There is a general tendency for the mounds to grow in size towards the shelf margin. Along the northern margin of the Silurian carbonate outcrop belt, the mounds of unit WG2 form complexes up to several hundred metres thick (fig. 6). Separation of unit WG1 and WG2 is often impossible in these shelf margin complexes. Unit WG2 weathers light grey and massive, and is a major cliff-forming unit.

Unit WG3. This unit consists of mainly dark grey to black back-mound and intermound sediments, and may contain isolated mounds up to $c .125 \mathrm{~m}$ thick (fig. 5). The intermound and back-mound sediments are thinly bedded, variably mottled lime mudstones with thin interbeds of graded bioclastic limestones, pebble conglomerates and slump sheets. Shale partings and thin shaly interbeds are also common and may contain abundant graptolites. Chert layers and nodules occur throughout. These sediments laterally drape on to, or terminate against, light to dark grey massive bedded carbonate mound sediments; close to the mounds bedding in the dark lime mudstones is very variable. Unit WG3 is recessive and weathers mainly dark grey to yellowish, except where mounds, which weather paler and are cliffforming, are present (fig. 5). The thickness of unit WG3 is very variable and is difficult to as- 

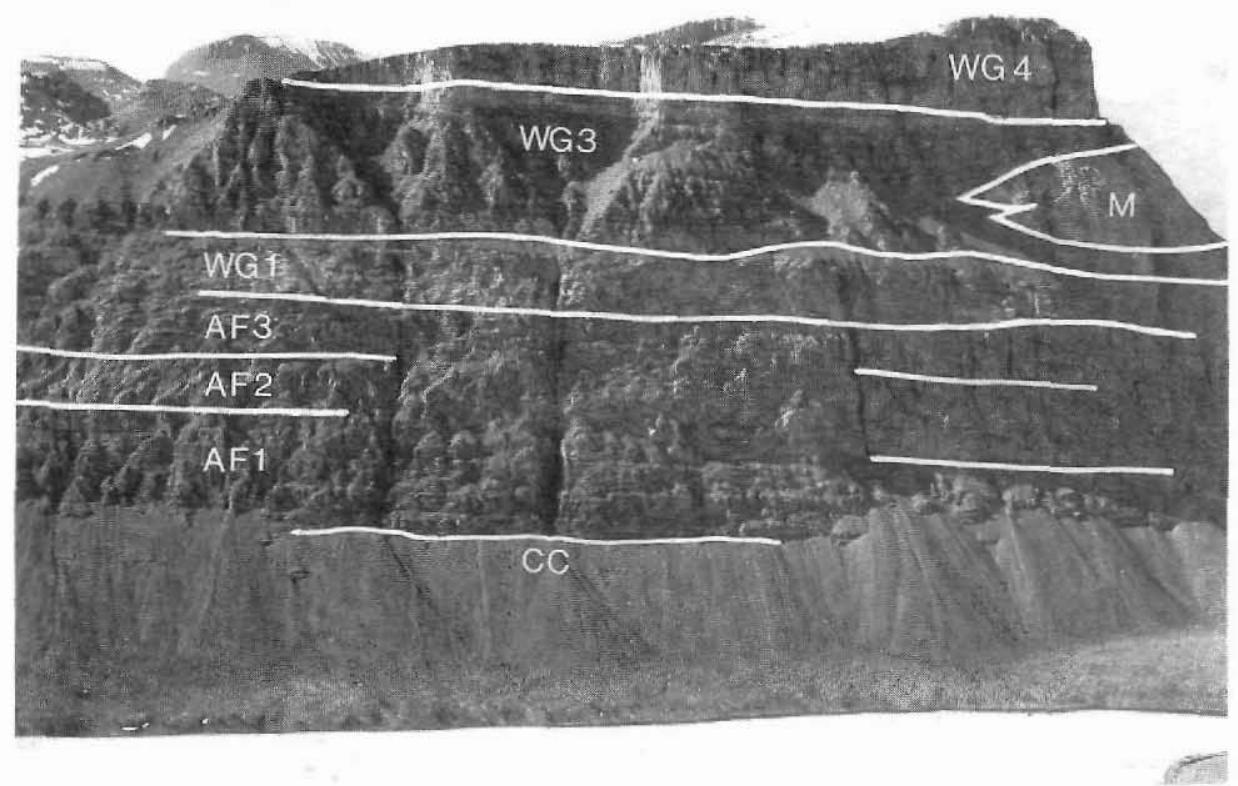

Fig. 5. Dark, somewhat recessive carbonates of unit WG3 containing a mound (M) c. $125 \mathrm{~m}$ thick. Unit WG3 overlies unit WG1, the top of which only shows slight mound development (hummocky bedding surfaces). Unit WG4 is seen at the cliff top as a light weathering stripy unit. North-western end of Apollo Sø. Cliff height $c .850 \mathrm{~m}$.

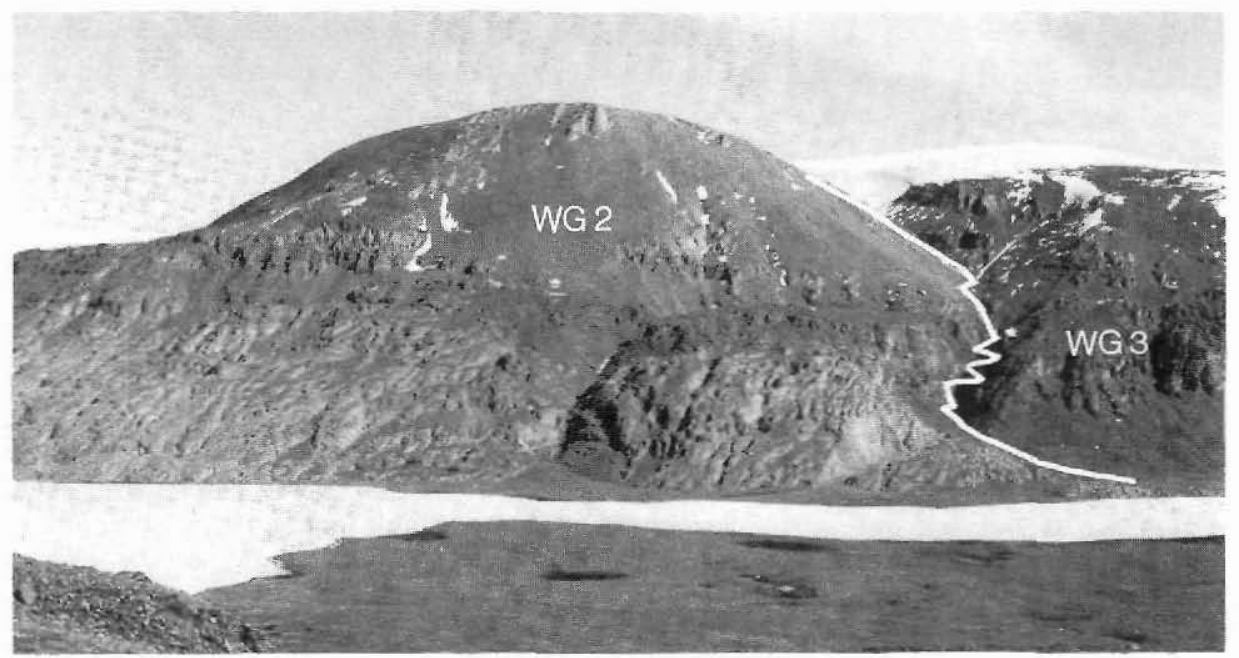

Fig. 6. Large unit WG2 mound complex at northern margin of carbonate outcrop belt. North end of 'Aphrodite $\mathrm{S}^{\prime}$ ' in Wulff Land. Height from lake level to top of mound c. $800 \mathrm{~m}$. 
certain, where mounds are common. This is particularly the case in the northern part of the Silurian carbonate outcrop belt, where mounds of this unit may interconnect with the large mounds of unit WG2. The darker lime mudstones, cherts and related sediments form sequences up to $250 \mathrm{~m}$ thick in eastern Warming Land and Wulff Land. Unit WG3 has not been certainly recognised to the east of Navarana Fjord.

Unit WG4. This unit is lithologically variable and is mainly composed of interbedded dark and light stromatoporoid and coral biostromes. In the dark beds the stromatoporoids and corals are in situ, while pale beds contain abundant reworked material. Crinoidal debris occurs virtually throughout, and pure encrinite beds up to $10 \mathrm{~m}$ thick are interbedded with the biostromes. In exceptional cases, sequences dominated almost exclusively by encrinites are up to $200 \mathrm{~m}$ thick, for example in eastern Hall Land. The unit is generally cliff-forming and its lithological variability produces a characteristic striped appearance in weathered outcrops (fig. 7). Thickness is variable, up to $400 \mathrm{~m}$ in the northern part of the Silurian carbonate outcrop belt. Well bedded sequences associated with the shelf margin complexes in western Freuchen Land and in the J. P. Koch Fjord area are reminiscent of unit WG4.

Unit WG5. The light grey and white to less commonly dark grey, fine-grained skeletal limestones forming unit WG5 are generally rich in stromatoporoids and large coral colonies. Limestone conglomerates are interbedded throughout, but increase in abundance and thickness upwards. Dips are variable and often steep (up to $30^{\circ}$ ); typically the beds dip and also thin southwards (fig. 7A), but northerly dips have been observed (fig. 7B). The unit is cliffforming and easily recognised by the combination of light weathering colours and steep dips. Unit WG5 forms the topographically highest parts of the Silurian carbonate sequence, but is not preserved east of Permin Land. Due to present-day erosion the top of the sequence is not seen, but exposed thicknesses range from $200 \mathrm{~m}$ to more than $1000 \mathrm{~m}$ in central Hall Land (Dawes, in press).

Correlation. Strata assigned to units WG1-5 clearly represent the continuation of the Washington Land Group of Hurst (1980a), which is thus extended eastwards from Washington Land across the entire region. Unit WG1 appears to be equivalent to the lower part of the Petermann Halvø Formation and the lower part of unit 1D in the Kap Ammen sequence (Dawes \& Peel, 1984). Unit WG2 is more difficult to correlate with described sequences, but it is probably equivalent to parts of the Petermann Halvø, Bessels Fjord, Pentamerus Bjerge and Adams Bjerg Formations and to the upper part of unit 1D at Kap Ammen. Unit WG3 is best considered equivalent to the Bessels Fjord Formation and unit 1E in the Kap Ammen sequence. It is possible that parts of the Cape Schuchert Formation of the Peary Land Group (Hurst, 1980a) may be equivalent to the cherty intermound facies of these units. Unit WG4 correlates with the Offley Island Formation and unit WG5 with the Cape Tyson Member of the Hauge Bjerge Formation as defined by Hurst (1980a). Other formations of the Washington Land Group defined and described by Hurst (1980a) have not been recognised outside Washington Land (fig. 2).

East of J. P. Koch Fjord units WG1-2 correlate with the Ymers Gletscher Formation and possibly parts of the shelf-rim facies of the Odins Fjord Formation of Hurst (1984). Units WG3-4 are equivalent to the bulk of the Odins Fjord Formation, while unit WG5 correlates with the Samuelsen Høj Formation of Hurst (1984; see also fig. 2). 

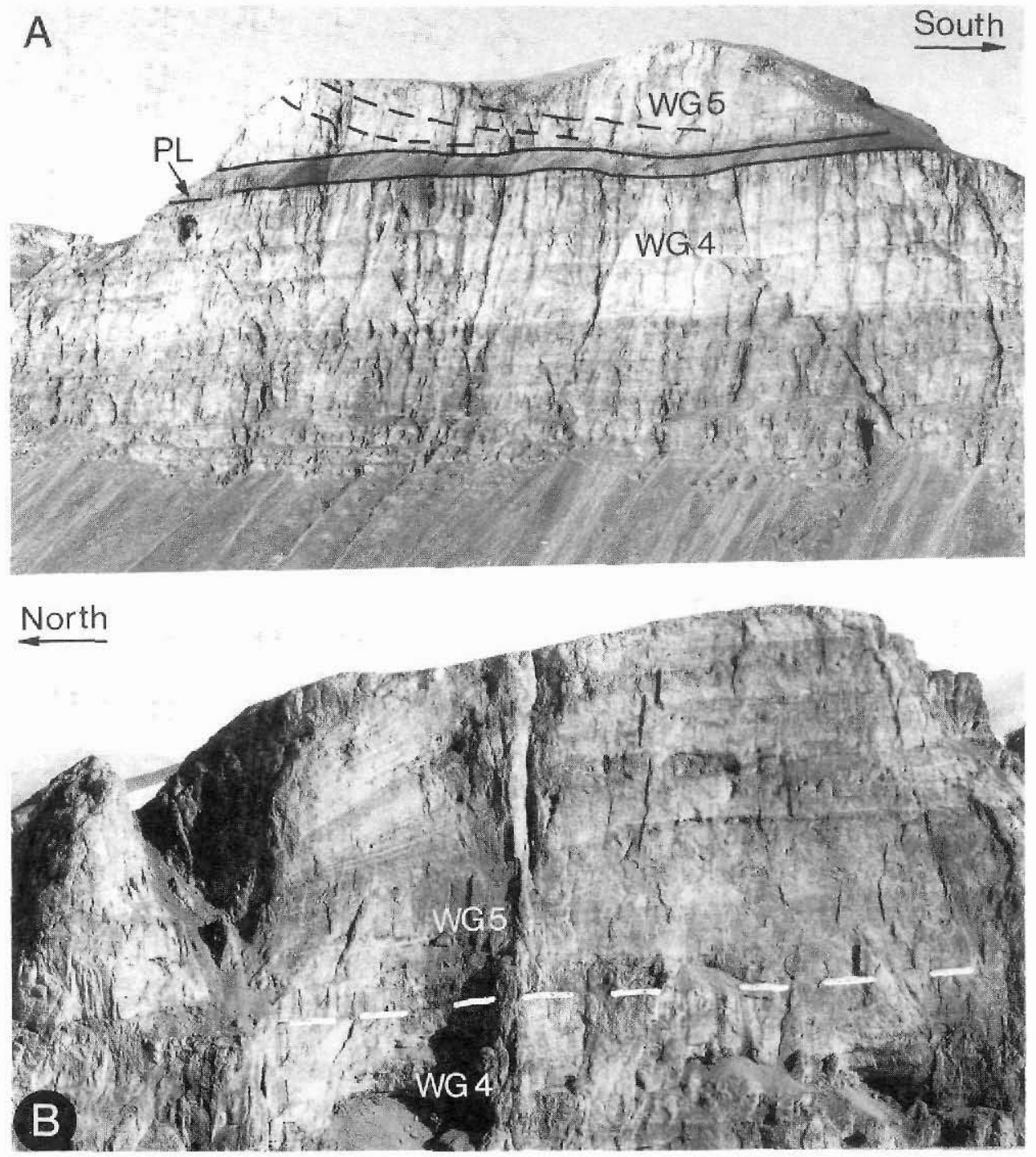

Fig. 7. A: Flatbedded, characteristically stripy carbonates of unit WG4, overlain by unit WG5 with beds dipping towards south. Unit WG4 and WG5 are separated by dark recessive carbonates of unit PL. West side of Dreyer Firn, Nyeboe Land. Cliff height $c$. $300 \mathrm{~m}$. B: Steep northerly dipping beds of unit WG5 overlying characteristically stripy WG4 at the margin of the carbonate outcrop belt in central Warming Land. Height of cliff visible c. $200 \mathrm{~m}$.

\section{Peary Land Group}

The black calcareous mudstones and siltstones which occur as a distinct unit along the northern margin of the carbonate outcrop belt (fig. 8) are for convenience assigned to the Peary Land Group (unit PL), but have not been examined in detail. However, sediments of 


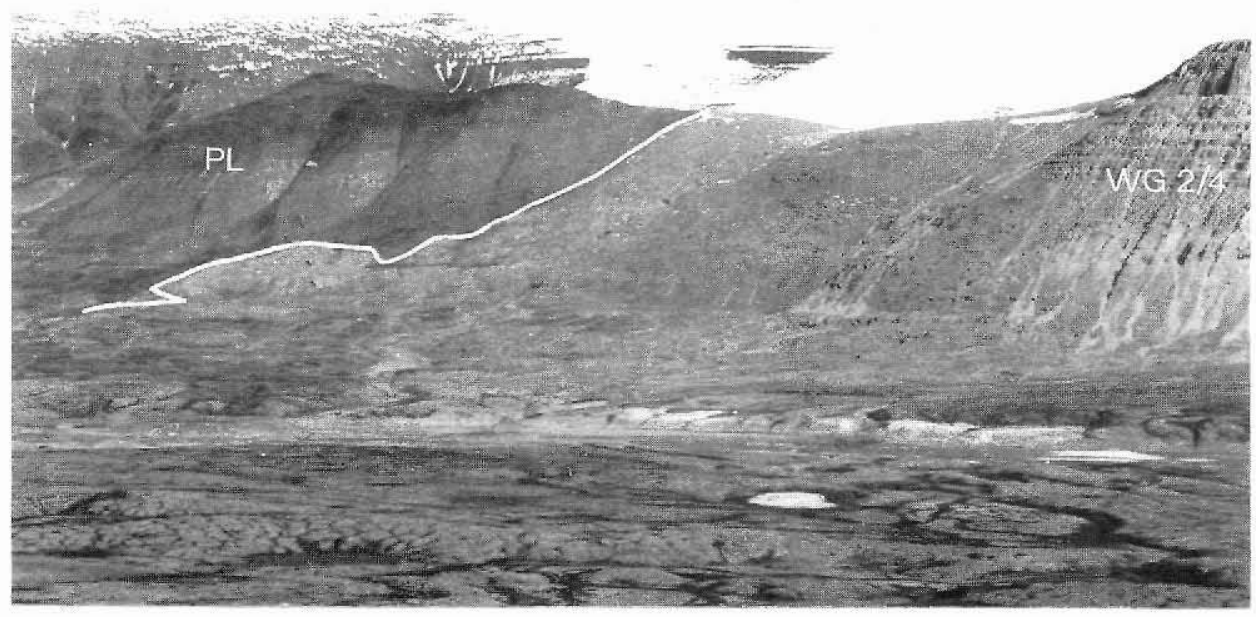

Fig. 8. Depositional contact between dark weathering clastic sediments of the Peary Land Group (PL) and the paler shelf edge carbonates as developed in eastern Wulff Land, north of Apollo Sø. Height of mountain to the right is $c .800 \mathrm{~m}$.

this unit also occur within the carbonate belt where the carbonate shelf margin is strongly indented. The black mudstones and siltstones are finely laminated or small-scale crosslaminated; basal surfaces commonly show scours or flutes.

The unit is laterally very variable, especially in the proximity of mounds of units WG2 and WG5. Towards the mounds the unit grades into black lime mudstone, often strongly chertified, with abundant intraformational shelly conglomerates, slumped beds and occasional carbonate conglomerates with out-size clasts and large isolated blocks of limestone.

The unit is very recessive, apart from the thicker conglomerates, and weathers black to pale yellowish-brown. Thickness has not been estimated as the upper part of the sequence was not examined, but thicknesses from 150 to $c .240 \mathrm{~m}$ have previously been reported (cf. Hurst \& Surlyk, 1982; Larsen \& Escher, 1985).

Correlation. The basinal and mound-related facies of unit PL appear to be equivalent to the Lafayette Bugt Formation of the Peary Land Group and the Kap Lucie Marie Formation of the Washington Land Group (Hurst, 1980a), respectively.

\section{Deposition}

Upper Ordovician - Silurian carbonates between Petermann Gletscher in the west and J. P. Koch Fjord in the east exhibit a uniform depositional history, although the formation of mounds has resulted in much lateral variation in thickness and lithology, particularly in the upper parts of the sequence. 

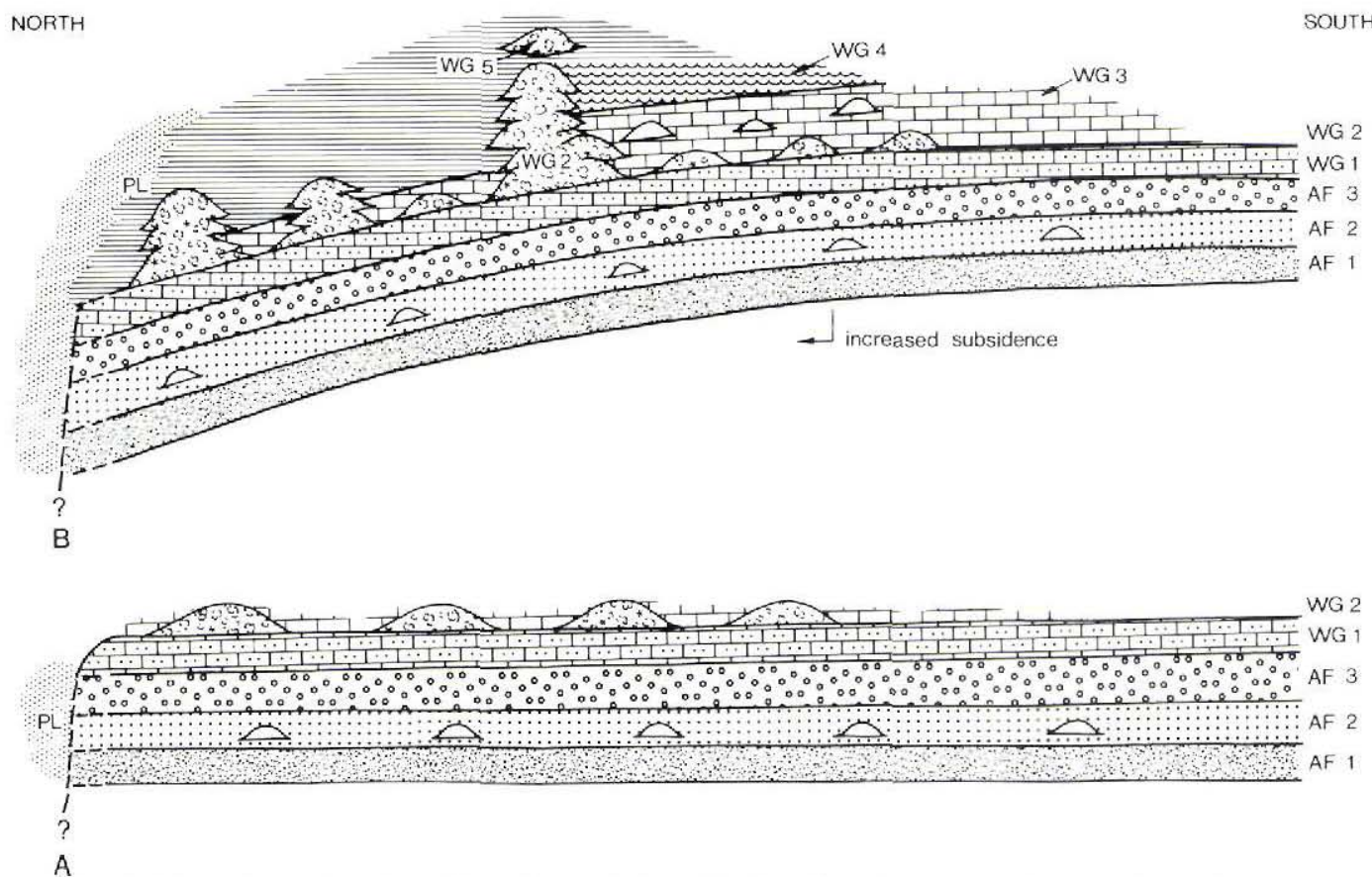

Fig. 9. Schematic cross section of the Upper Ordovician - Silurian outcrops showing mapping units and the general depositional history. A: early stage deposition on an extensive and uniformly subsiding shelf, B: late stage deposition related to increased subsidence at the northern part of the shelf. AF1: mottled limestones with Maclurites, AF2: light grey biostromal limestones, AF3: dark mixed skeletal limestones with abundant pentameroids, locally with paler top (transitional to unit WG1), WG1: bedded variable skeletal pale limestones; dolomite at base in south, WG2: limestone with mounds, very large in north, smaller to absent in south, WG3: variable intermound sediments and small mounds, WG4: pale and dark biostromal limestones, encrinites and skeletal limestones, WG5: erratically dipping, variable, mound-related limestones; includes conglomerates and encrinites, PL: dark shale with boulder conglomerate and limestone gravel beds.

The regional uniformity in the lower part of the sequence (units AF1-3, WG1 and part of WG2) reflects sedimentation on an extensive and uniform shelf. The shelf was bounded by an escarpment to the north, as seen in Navarana Fjord and J. P. Koch Fjord (Surlyk et al., 1980; Surlyk \& Hurst, 1984; Surlyk \& Ineson, 1987). The presence of the escarpment further to the west, in northern Nyeboe Land and north of Hall Land (see fig. 1), is inferred from stratigraphic considerations and from changes in the style of tectonic deformation (Hurst \& Surlyk, 1982; Larsen \& Escher, 1985; Escher \& Larsen, 1987). Slight variations within unit WG1 (dolomitisation in southerly areas) and the increase in numbers of mounds towards the north (unit WG2) probably indicates a slight deepening from peritidal, possibly partly emergent environments in the south to shallow subtidal outer shelf environments in the north (fig. 9A).

Subsequent deposition shows much more lateral variation which was apparently related to increased subsidence north of a hinge line running from northern Bessels Fjord in Washing- 
ton Land to southern Nares Land (fig. 1). This increased subsidence of the northern part of the shelf and deposition of the sediments of the Peary Land Group (unit PL, figs $1 \& 9 B$ ) effectively terminated carbonate deposition; only large outlying mounds were maintained after the initial onset of deepening (cf. Hurst, 1980b; Surlyk \& Hurst, 1984; Larsen \& Escher, 1985).

As a result of the subsidence a new shelf margin was developed further to the south, represented by the reef belt seen from central Hall Land to south-western Freuchen Land (fig. 1). South of this, an essentially flat shelf, probably sloping gently northwards, was maintained. The major mound complexes fringing the shelf continued their growth from preexisting mounds (unit WG2). These complexes, with their associated gravity flow deposits, did not maintain a complete barrier across the region. A steep, indented shelf margin developed with sheltered areas between and behind the major complexes being the sites for deposition of dark lime mudstones and bioclastic wackestones which form the thicker parts of unit WG3. Further south on the shelf, similar sediments occur in thinner packets as intermound deposits between smaller intra-shelf mounds of unit WG3 (see also Hurst, 1980b). Local encrinite shoals (unit WG4) fringed some of the major mounds, and these were reworked southwards onto the shelf or northwards off the shelf, where they form steep dipping lime sands on the basin slope. Where mounds were not maintained, laterally extensive biostromal deposits developed (unit WG4).

The continuing relative rise in sea level culminated in the drowning of the whole shelf, probably during latest Llandovery time (cf. Hurst, 1980a, 1984; Hurst \& Surlyk, 1982). The latest preserved stage of carbonate deposition (unit WG5) was therefore very local in its distribution. Deposition during this stage appears to have been restricted to the tops of the major mound complexes which, by this time, were almost completely surrounded by muds of unit PL (fig. 9B).

Due to the present-day erosion level it is not known how long carbonate deposition continued in North Greenland. Hurst (1980a) and Dawes \& Peel (1984) reported faunas of Early Ludlow age from the carbonate sequence in unit WG5, although thin limestone beds of Pridoli (latest Silurian) age occurring within the siltstone-dominated Chester Bjerg Formation in western Hall Land (Dawes \& Peel, 1984) may suggest that parts of the carbonate platform survived until the close of the Silurian.

Acknowledgements. We are thankful to A. K. Higgins and F. Surlyk for critically reviewing the manuscript and to B. Sikker Hansen, B. Skall-Jensen, B. Thomas, J. Fernqvist and J. Lautrup for technical assistance.

\section{References}

Christie, R. L. \& Peel, J. S. 1977: Cambrian-Silurian stratigraphy of Børglum Elv, Peary Land, eastern North Greenland. Rapp. Grønlands geol. Unders. 82, 48 pp.

Dawes, P. R. in press: Topographical and geological maps of Hall Land, North Greenland $\left(81^{\circ}-82^{\circ} \mathrm{N}\right)$; description of Lower Palaeozoic and surficial geology. Bull. Grønlands geol. Unders. 155.

Dawes, P. R. \& Peel, J. S. 1984: Biostratigraphic reconnaissance in the Lower Palaeozoic of western North Greenland. Rapp. Grønlands geol. Unders. 121, 19-51.

Escher, J. C. \& Larsen, P.-H.: The buried western extension of the Navarana Fjord escarpment in central and western North Greenland. Rapp. Grønlands geol. Unders. 133, 81-89.

Henriksen, N. 1987: Systematic geological mapping in 1985 in central and western North Greenland. Rapp. Gronlands geol. Unders. 133, 5-12. 
Hurst, J. M. 1979: Uppermost Ordovician and Silurian geology of north-west Peary Land, North Greenland. Rapp. Grønlands geol. Unders. 88, 41-49.

Hurst, J. M. 1980a: Silurian stratigraphy and facies distribution in Washington Land and western Hall Land, North Greenland. Bull. Grønlands geol. Unders. 138, 95 pp.

Hurst, J. M. 1980b: Paleogeographic and stratigraphic differentiation of Silurian carbonate buildups and biostromes of North Greenland. Bull. Am. Ass. Petrol. Geol. 64, 527-548.

Hurst, J. M. 1984: Upper Ordovician and Silurian carbonate shelf stratigraphy, facies and evolution, eastern North Greenland. Bull. Grønlands geol. Unders. 148, 73 pp.

Hurst, J. M. \& Surlyk, F. 1982: Stratigraphy of the Silurian turbidite sequence of North Greenland. Bull. Grønlands geol. Unders. 145, $121 \mathrm{pp.}$

Larsen, P.-H. \& Escher, J. C. 1985: The Silurian turbidite sequence of the Peary Land Group between Newman Bugt and Victoria Fjord, western North Greenland. Rapp. Grønlands geol. Unders. 126, 47-67.

Peel, J. S. \& Hurst, J. M. 1980: Late Ordovician and early Silurian stratigraphy of Washington Land, western North Greenland. Rapp. Grønlands geol. Unders. 100, 18-24.

Surlyk, F. \& Hurst, J. M. 1984: The evolution of the early Paleozoic deep-water basin of North Greenland. Bull. geol. Soc. Am. 95, 131-154.

Surlyk, F. \& Ineson, J. R. 1987: Aspects of Franklinian shelf, slope and trough evolution and stratigraphy in North Greenland. Rapp. Grønlands geol. Unders. 133, 41-58.

Surlyk, F., Hurst, J. M. \& Bjerreskov, M. 1980: First age-diagnostic fossils from the central part of the North Greenland foldbelt: Nature, Lond. 286, 800-803.

Troelsen, J. C. 1949: Contributions to the geology of the area round Jørgen Brøndlunds Fjord, Peary Land, North Greenland. Meddr. Grønland 149(2), $29 \mathrm{pp.}$ 